\title{
FATAL HAEMOLYTIC URAEMIC SYNDROME AND IDIOPATHIC HYPERLIPAEMIA IN MONOZYGOTIC TWINS
}

\author{
BY \\ S. CAMPBELL and I. J. CARRE \\ From the Department of Child Health, the Queen's University of Belfast, and the Royal Belfast Hospital for Sick Children
}

(RECEIVED FOR PUBLICATION APRIL 20, 1965)

In 1932 Bürger and Grütz described a previously unrecognized disorder characterized by triglyceride hyperlipaemia with variable clinical features, including attacks of abdominal pain, xanthomatous skin lesions, and hepatosplenomegaly. This condition is now usually called 'idiopathic hyperlipaemia' (Hsia, 1959).

More recently, Gasser, Gautier, Steck, Siebenmann, and Oechslin (1955) have defined the haemolytic-uraemic syndrome in young children. The features of this condition are renal damage with uraemia, a haemolytic anaemia with fragmentation of red blood cells, and thrombocytopenia.

In this report we record the association of these two relatively rare conditions in monozygotic twins.

\section{Case Reports}

Twin girls, the first children of young unrelated parents, were born in hospital on March 3, 1961. The mother was told the twins were identical; each weighed $4 \mathrm{lb}$. $(1 \cdot 8 \mathrm{~kg}$.). The neonatal period was uneventful and they were discharged from the maternity hospital when $5 \frac{1}{2} \mathrm{lb}$. $(2 \cdot 5 \mathrm{~kg}$.).

Twin I. On August 30, 1961, she was admitted to the Royal Belfast Hospital for Sick Children. She had been ill for 12 hours with a cough, vomiting, and rapid breathing. On examination her temperature was $102^{\circ} \mathrm{F} .\left(38 \cdot 9^{\circ}\right.$ C.) due to a chest infection; this was treated with a 5-day course of sulphadimidine. The haemoglobin on admission was $8 \mathrm{~g}$./ $100 \mathrm{ml}$.; 6 days later this had fallen to $6 \cdot 2 \mathrm{~g}$./ $100 \mathrm{ml}$. (Fig. 1).

By September 7, 8 days after admission, she had become extremely pale and was passing blood-stained urine. There was no evidence of oedema.

Investigations. Urinalysis showed albumin +++ , red cells ++ . There was no evidence of a urinary infection. Blood urea $120 \mathrm{mg}$. $/ 100 \mathrm{ml}$. Plasma proteins, total $4 \mathrm{~g} . / 100 \mathrm{ml}$.: albumin $2.06 \mathrm{~g}$. $/ 100 \mathrm{ml}$., globulin 1.94 g./100 ml. $\left(\alpha_{1}, 0.33 ; \alpha_{2}, 0.51 ; \beta, 0.51, \gamma, 0.59\right)$. Haemoglobin $3 \mathrm{~g} . / 100 \mathrm{ml}$. Red cells $1.2 \times 10^{6} / \mathrm{c} . \mathrm{mm}$., PCV $12 \%$, MCV $100 \mu^{3}$, MCHC $25 \%$, reticulocytes $27 \%$, white cells $18,000 / \mathrm{c} . \mathrm{mm}$., mostly lymphocytes; platelet count $136,000 /$ c.mm. Serum bilirubin $0.2 \mathrm{mg} . / 100 \mathrm{ml}$. A blood film showed bizarre poikilocytosis with fragmentation of red cells and the presence of 'burr' forms (Fig. 2).

A blood transfusion of $100 \mathrm{ml}$. raised the haemoglobin to $6.4 \mathrm{~g} . / 100 \mathrm{ml}$. Within 5 days of the transfusion the haemoglobin had fallen to $4.8 \mathrm{~g} . / 100 \mathrm{ml}$., and the blood urea had risen to $156 \mathrm{mg} . / 100 \mathrm{ml}$.; a second transfusion $(130 \mathrm{ml}$.$) was given, which raised the haemoglobin to$ $6.7 \mathrm{~g} . / 100 \mathrm{ml}$.

By September 21, the haemoglobin had fallen to $4.9 \mathrm{~g}$./ $100 \mathrm{ml}$. and a third transfusion of $100 \mathrm{ml}$. was given. At this time the blood urea was $162 \mathrm{mg} / 100 \mathrm{ml}$. and a platelet count $88,000 /$ c.mm.; her blood pressure was recorded as $150 / 95 \mathrm{~mm} . \mathrm{Hg}$. Following transfusion the haemoglobin rose to $8 \mathrm{~g}$. $/ 100 \mathrm{ml}$. During the next week the child became very ill; she developed oedema and oliguria, a further rise in blood urea to $250 \mathrm{mg} . / 100 \mathrm{ml}$., a severe acidosis $\left(\mathrm{CO}_{2} \mathrm{CP} 7.5 \mathrm{mEq} / \mathrm{l}.\right)$, and a drop in haemoglobin to $4.9 \mathrm{~g} . / 100 \mathrm{ml}$. Resonium A was given rectally because of a rise in serum potassium to $7.5 \mathrm{mEq} / \mathrm{l}$. She died suddenly on October 1 .

Twin II. The other twin was admitted to hospital on September 11, 1961, 12 days after her sister (Fig. 1). She had been ill for two days with an upper respiratory tract infection and vomiting. Apart from pallor there were no abnormal clinical findings.

Investigations. Urinalysis showed albumin ++ with microscopic haematuria; there was no evidence of a urinary infection. Blood urea $87 \mathrm{mg} . / 100 \mathrm{ml}$. Plasma proteins, total $4 \mathrm{~g} . / 100 \mathrm{ml}$.: albumin $2 \mathrm{~g} . / 100 \mathrm{ml}$., globulin $2 \mathrm{~g}$. $/ 100 \mathrm{ml} .\left(a_{1}, 0.35, a_{2}, 0.53, \beta, 0 \cdot 59, \gamma, 0.53\right)$. Haemoglobin $4 \cdot 2$ g. $/ 100 \mathrm{ml}$. Red cells $1.5 \times 10^{6} / \mathrm{c} . \mathrm{mm}$., PCV $16 \%$, MCV $106 \mu^{3}$, MCHC $26 \%$, reticulocytes $12 \%$, white cells $19,400 /$ c.mm., platelets $88,000 /$ c.mm. Serum bilirubin $0.2 \mathrm{mg} . / 100 \mathrm{ml}$. A blood film showed the same bizarre poikilocytosis of the red cells as in Twin I. 

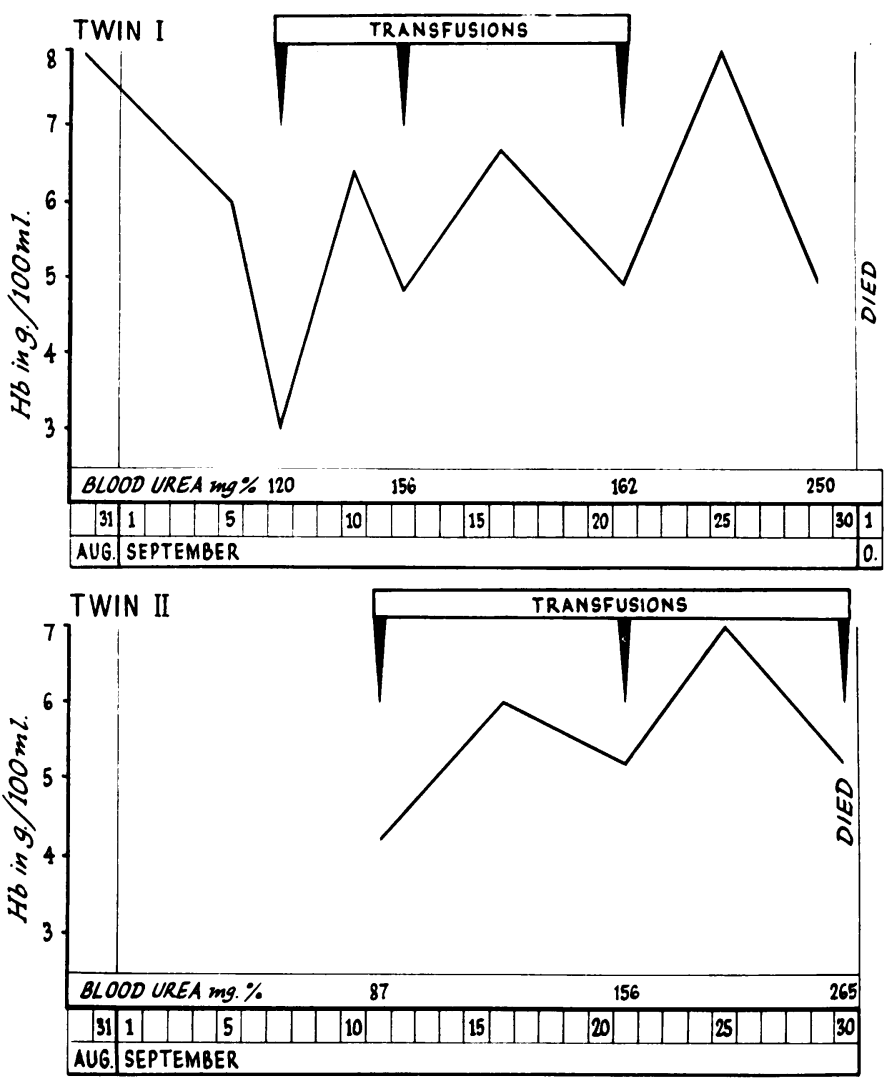

FIG. 1.-Summary of the terminal illness in twins I and II.

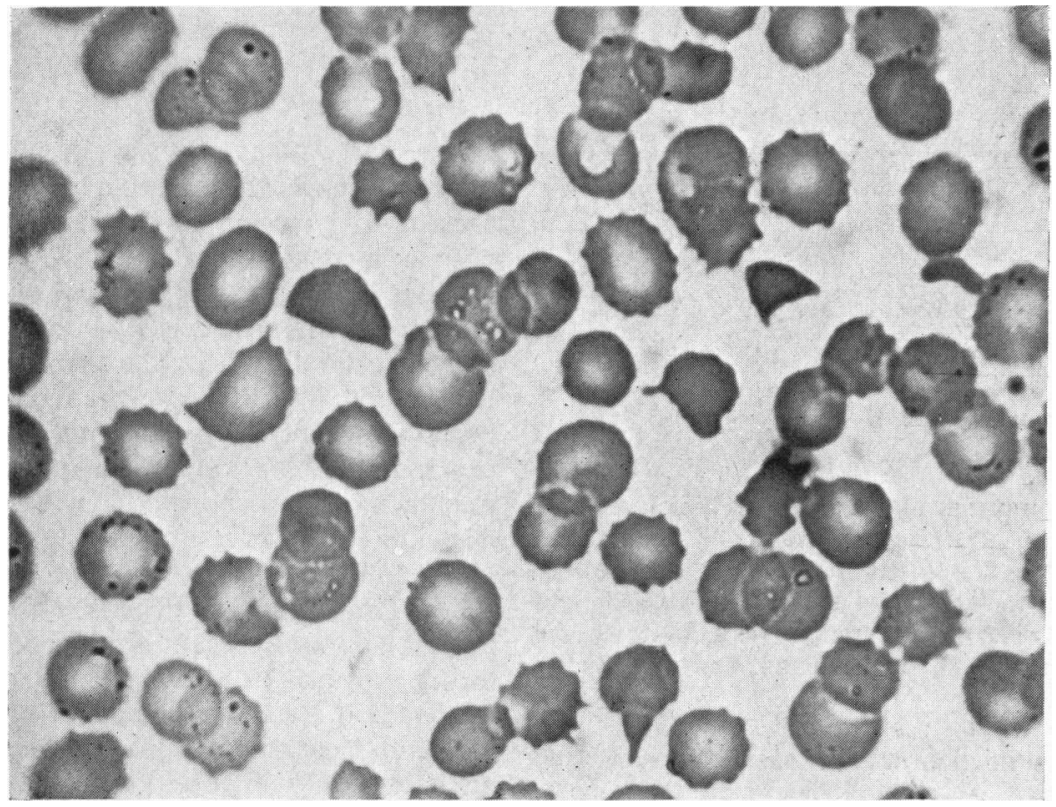

FIG. 2.-Blood film showing bizarre poikilocytosis of red cells. (Leishman. $\times 750$.) 
A blood transfusion $(160 \mathrm{ml}$.) raised the haemoglobin to $6 \mathrm{~g} . / 100 \mathrm{ml}$.

By September 21 , the haemoglobin had fallen to $5 \cdot 2 \mathrm{~g}$./ $100 \mathrm{ml}$. and the reticulocyte count had risen to $34 \%$; her blood pressure was recorded as $200 / 150 \mathrm{~mm} . \mathrm{Hg}$ and the blood urea as $156 \mathrm{mg} . / 100 \mathrm{ml}$. A further transfusion $(160 \mathrm{ml}$.) was given and the haemoglobin rose to $7 \mathrm{~g}$. $/$ $100 \mathrm{ml}$. Nine days after transfusion the haemoglobin had fallen to $5 \cdot 2 \mathrm{~g} . / 100 \mathrm{ml}$. and the blood urea had risen to $265 \mathrm{mg}$. $/ 100 \mathrm{ml}$. She was given a third transfusion (100 ml.). She died the same evening.

\section{Comment}

No purpura, jaundice, xanthomata, hepatosplenomegaly, or retinal changes were noted in either twin during their illness. There was no history of drug therapy before admission to hospital. No evidence was obtained of a streptococcal infection. Except for a slight increase in red cell fragility, investigations aimed at defining a cause for the haemolytic anaemia in both babies were unrewarding: direct Coombs test was negative; no atypical red cell antibodies or abnormal haemoglobin were detected; no deficiency of glucose-6-phosphate dehydrogenase was demonstrated; the blood Wassermann reaction was negative.

Shortly after the admission to hospital of twin II it was noted that the serum of both infants was milky white. Biochemical estimation of serum lipids on pooled serum confirmed a marked increase in triglycerides associated with an increase in cholesterol and phospholipids (serum from each infant was inadvertently pooled before analysis). The fasting serum lipids of the father and of a sister born subsequent to the death of the twins were normal. Serum from the mother, who was symptom free, showed an increase in triglyceride, cholesterol, and phospholipid values (Table).

TABLE

SERUM LIPIDS OF FAMILY

\begin{tabular}{|c|c|c|c|}
\hline & $\underset{\text { (mEq/1.) }}{\text { Triglycerides }}$ & $\begin{array}{c}\text { Cholesterol } \\
\text { (mg./100 ml.) }\end{array}$ & $\begin{array}{l}\text { Phospholipids } \\
\text { (mg./100 ml.) }\end{array}$ \\
\hline Normal range* & $2 \cdot 78 \pm 0.9$ & $206 \pm 26$ & $241 \pm 35$ \\
\hline $\begin{array}{l}\text { Father } \ldots \\
\text { Mother } \ldots \\
\text { Twins' pooled } \\
\text { Swerum } \\
\text { Sister } \quad \ldots\end{array}$ & $\begin{array}{r}2 \cdot 21 \\
8 \cdot 38 \\
52 \cdot 09 \\
0 \cdot 68\end{array}$ & $\begin{array}{r}172 \\
280 \\
354 \\
94\end{array}$ & $\begin{array}{l}183 \\
324 \\
552 \\
132\end{array}$ \\
\hline
\end{tabular}

* Normal range for methods used (Hayes and Neill, 1964).

No information was available regarding the placenta or foetal membranes. However, the results of blood group typing on the twins supported the statement made to the mother while in the maternity hospital that the babies were identical twins; no differences were found in the ABO, Rhesus, MN, S, P, Kell, Cellano, Lewis and Duffy blood groups.

Pathology. Permission was obtained for a limited examination only. Necropsy findings were the same in the two children. The pancreas, heart, and coronary vessels showed no abnormality. Fatty globules were present in the alveolar wall capillaries of the lungs, and in some liver and Kupffer cells, though no great intracellular increase in fat was evident. In the spleen fine droplets of fat were seen in cells lining veins and sinuses. There was no evidence of abnormal fat storage in the bone-marrow.

The kidneys showed marked pathological changes. In both children they were swollen to about twice the normal size. The capsule stripped easily revealing a smooth surface with fine purple mottling.

Histologically, primitive glomeruli where present were normal. All the definitive glomeruli, however, were damaged. Some were enlarged with swollen individual capillary loops; many showed necrotic changes while others were atrophic. Many glomerular tufts were occluded by fibrin plugs. Tubular changes appeared to be mostly secondary to the glomerular damage. Some were atrophied and others dilated; many contained casts of protein and red cells. There was no histological evidence of infection or glomerulonephritis.

Staining with Scharlach $\mathbf{R}$ showed the glomerular tufts to be full of lipid contained within the glomerular capillaries (Fig. 3). Further staining with SmithDietrich stain suggested that some of this fatty material was phospholipid. Schultz stain for cholesterol was indefinite. In contrast with the glomerular findings there was very little lipid in the tubular epithelium.

The lipid in the kidneys was shown by biochemical analysis to be mainly cholesterol, the cholesterol content of the kidneys being four times greater than that of the kidneys of another child of the same age. On the other hand, there was no biochemical evidence of an increase in renal phospholipid or triglyceride content. These observations differ noticeably from the blood findings of a very high triglyceride level with only moderate increases in phospholipid and cholesterol values. We have no satisfactory explanation for these findings.

\section{Discussion}

The diagnosis of idiopathic hyperlipaemia in these 6-month-old monozygotic twins was made on the basis of a milky serum with the typical biochemical findings of a marked increase in serum triglycerides associated with a moderate increase in phospholipid and cholesterol levels. The disorder is thought to be transmitted by an autosomal recessive gene. The observations noted in our family agree with this explanation. The occurrence of the disease in both members of monozygotic twins would be expected. The finding of raised serum lipids in the mother points to her being a heterozygote carrier of the gene (Boggs, Hsia, Mais, and Bigler, 1957). On the other hand, the normal serum lipid levels recorded in the father do not rule out the heterozygote state, since fat loading tests may be necessary to unmask a carrier of the abnormal gene. These tests may show an abnormally high serum lipid or slow rate of clearance of chylomicrons from the plasma (Bialkin, 


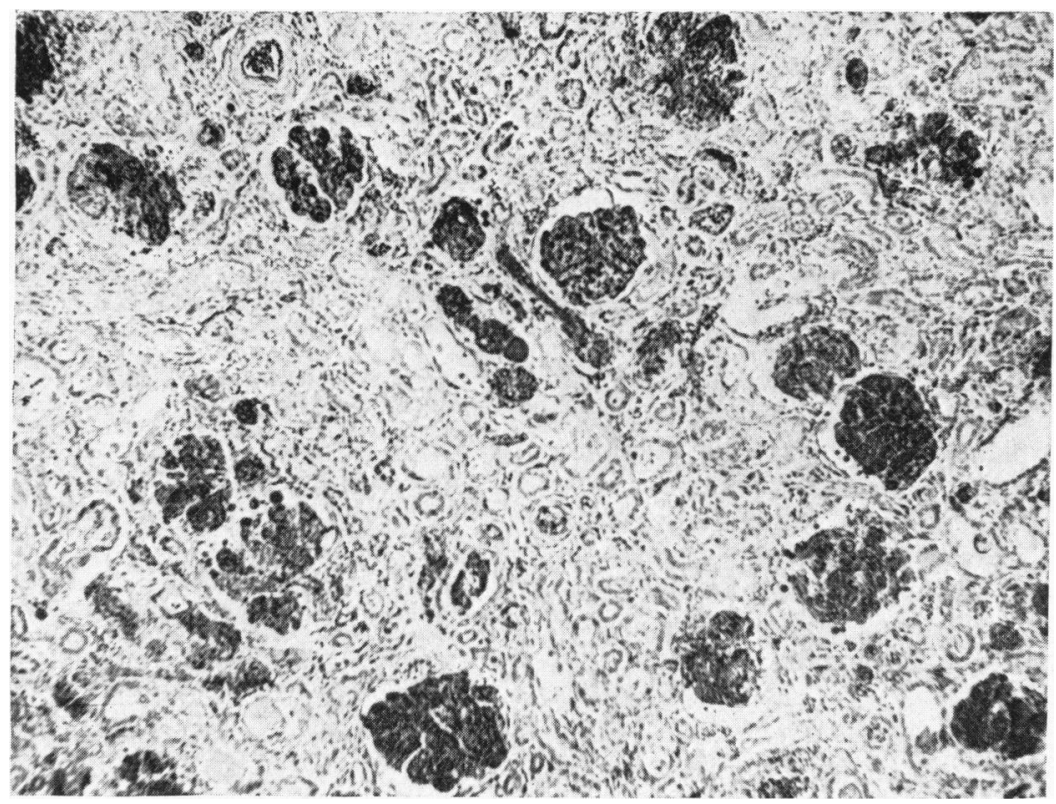

FIG. 3.-Lipid (stained black) in capillaries of renal glomeruli. (Scharlach R. $\times 60$.)

Zucker, Sklarin, Hirschhorn, and Davidson, 1962). Unfortunately it proved impossible to carry out such studies on this family as permission for further investigation was refused by the parents and other relatives.

There have been few reports of idiopathic hyperlipaemia in childhood (Rausen and Adlersberg, 1961) and death in infancy seems to be exceedingly rare. Only two necropsy reports on young children have been traced. Chapman and Kinney (1941) described the post-mortem findings in a boy aged 21 months who was known to have had idiopathic hyperlipaemia: no adequate cause for his death was found. Baba and Volk (1964) reported the findings in a female infant aged 7 months who was dead on arrival at hospital. The diagnosis of idiopathic hyperlipaemia was made at necropsy. This infant died of an 'overwhelming pneumococcal septicaemia secondary to myelophthisic anaemia and leukopenia caused by replacement of the bone-marrow by severe deposition of lipids'.

The fatal malignant hyperlipaemia described by Hagberg, Hultquist, Svennerholm, and Voss (1964) in sibs of 9 and 15 weeks and by Lusher and Farber (1964) in a $4 \frac{1}{2}$-month-old boy probably constitutes a different entity. The characteristic features of the disorder as described by Hagberg et al. were a familial occurrence, triglyceride hyperlipaemia, a clinical picture of acute reticuloendotheliosis with progressive pancytopenia and hepatosplenomegaly, and neutral fat-containing granuloma-like cell infiltrations in different organs. Hepatosplenomegaly, pancytopenia, and granulomatous infiltrations did not occur in our patients.

Although it is plain that the twins described in this report died from the haemolytic-uraemia syndrome, the relation of this disorder to their idiopathic hyperlipaemia is uncertain. Khachadurian and Obeid (1964) have recently reported a male patient of 35 years with idiopathic hyperlipaemia who, during crises of abdominal pain, had albuminuria. Clinical evidence of renal involvement does not seem to have been previously described and we have been unable to trace a single necropsy report of renal damage in this disease. In the two children with idiopathic hyperlipaemia reported by Chapman and Kinney (1941) and Baba and Volk (1964) the kidneys were recorded as normal.

The cause of the haemolytic-uraemic syndrome is unknown, though a viral aetiology has been suggested (Gianantonio, Vitacco, Mendilaharzu, Rutty, and Mendilaharzu, 1964). Reported necropsy findings in the kidneys of children dying from this condition have varied widely. However, a striking feature in many has been widespread patchy glomerular damage characterized by intracapillary thrombi and necrosis (Alison, 1957; Gianantonio et al., 1964; Shinton, Galpine, Kendall, and Williams, 1964). 
With so little known regarding the pathogenesis of the haemolytic-uraemic syndrome we can only speculate on the course of events in our patients. The terminal illness in each twin started with an upper respiratory infection, of probable viral aetiology. It is tempting to postulate glomerular damage occurring in association with this infection with lipid being subsequently deposited in damaged glomerular capillaries due to the coincidental existence of idiopathic hyperlipaemia. This deposition of lipid may well have converted a potentially reversible renal disorder into an irreversible one. An alternative explanation, though in our opinion a less likely one, is that glomerular capillaries were primarily occluded by lipid which secondarily resulted in the development of the haemolyticuraemic syndrome. Either explanation would imply that idiopathic hyperlipaemia may not be as benign a disorder in children as is generally believed.

\section{Summary}

Monozygotic twin girls with idiopathic hyperlipaemia who died with the haemolytic-uraemic syndrome at 6 months of age are reported. Serum lipid levels in the parents and a younger sister are recorded.

Histologically, glomerular tufts were shown to be full of lipid. It is postulated that this deposition of lipid occurred within damaged glomerular capillaries.

Attention is drawn to the fact that idiopathic hyperlipaemia may not be as benign a disease in childhood as is usually believed.
We wish to thank Dr. D. Carson for the pathology report and Dr. D. Hayes and Mr. D. W. Neill for the serum lipid estimations.

\section{REFERENCES}

Alison, A. C. (1957). Acute haemolytic anaemia with distortion and fragmentation of erythrocytes in children. Brit. J. Haemat., 3, 1.

Baba, N., and Volk, T. L. (1964). Idiopathic hyperlipemia. Amer. J. Dis. Child., 108, 633.

Bialkin. G., Zucker, S., Sklarin, B. S., Hirschhorn, K., and Davidson, M. (1962). A genetic and metabolic study of a family with hyperlipemia. Pediatrics, 29, 566.

Boggs, J. D., Hsia, D. Y.-Y., Mais, R. F., and Bigler, J. A. (1957). The genetic mechanism of idiopathic hyperlipemia. New Engl. J. Med., 257, 1101.

Bürger, M., and Grütz, O. (1932). Über hepatosplenomegale Lipoidose mit xanthomatösen Veränderungen in Haut und Schleimhaut. Arch. Derm. Syph. (Berl.), 166, 542.

Chapman, F. D., and Kinney, T. D. (1941). Hyperlipemia: "idiopathic lipemia". Amer. J. Dis. Child., 62, 1014.

Gasser, C., Gautier, E., Steck, A., Siebenmann, R. E., and Oechslin, R. (1955). Hämolytisch-urämische Syndrome. Bilaterale Nierenrindennekrosen bei akuten erworbenen hämolytischen Anämien. Schweiz. med. Wschr., 85, 905.

Gianantonio, C., Vitacco, M., Mendilaharzu, F., Rutty, A., and Mendilaharzu, J. (1964). The hemolytic-uremic syndrome. J. Pediat., 64, 478.

Hagberg, B., Hultquist, G., Svennerholm, L., and Voss, H. (1964). Malignant hyperlipemia in infancy. Amer. J. Dis. Child., 107, 267.

Hayes, D., and Neill, D. W. (1964). Serum cholesterol and triglycerides in ischaemic heart disease. Clin. Sci., 26, 185.

Hsia, D. Y.-Y. (1959). Inborn Errors of Metabolism. Year Book Publishers, Chicago.

Khachadurian, A. K., and Obeid, A. I. (1964). Neuropathy in essential familial hyperlipaemia. Lancet, $2,911$.

Lusher, J., and Farber, S. D. (1964). Another case of malignant hyperlipemia in infancy? Amer. J. Dis. Child., 108, 211.

Rausen, A. R., and Adlersberg, D. (1961). Idiopathic (hereditary) hyperlipemia and hypercholesteremia in children. Pediatrics, 28, 276.

Shinton, N. K., Galpine, J. F., Kendall, A. C., and Williams, H. Parry (1964). Haemolytic anaemia with acute renal disease. Arch. Dis. Childh., 39, 455. 